\title{
Mature Teratoma
}

National Cancer Institute

\section{Source}

National Cancer Institute. Mature Teratoma. NCI Thesaurus. Code C9015.

A teratoma which may be cystic; it is composed entirely of well differentiated, adult-type mature tissues, without evidence of fetal-type immature tissues (grade 0 teratoma). 